\title{
Entrepreneurial Orientation Components and Sales Volume of Selected Quoted Consumer Goods Manufacturing Companies in Nigeria
}

\author{
Alase, Peter O. PhD ${ }^{1 *} \quad$ Babalola, Edward, A. $\mathrm{PhD}^{2} \quad$ Okusanya, A. O. PhD. ${ }^{3}$. \\ 1. Lecturer, Dept.of Management and Entrepreneurial Studies, Afe Babalola University, Ado-Ekiti \\ 2. Reader, Dept. of Management and Entrepreneurial Studies, Afe Babalola University, Ado-Ekiti \\ 3.Lecturer, Dept. of Business Education, Tai Solarin University of Education, Ijagun, Ijebu-Ode
}

\begin{abstract}
Organisational performance is of high importance and occupies a central position among other goals and remains a compensation for sustainable and competitive sales volume. Consumer goods manufacturing industry in Nigeria are experiencing decline in sales volume due to poor entrepreneurial orientation. This study examined the interaction between entrepreneurial orientation components and sales volume of selected quoted consumer goods manufacturing companies in Nigeria. The study adopted cross sectional survey design. The population of the study was 1,551 . Total enumeration was used to sample the entire population. A structured questionnaire was used for data collection. The Cronbach's alpha ranges between 0.721 and 0.892 . The response rate was $90.5 \%$. Data were analysed using descriptive and inferential statistics. Findings revealed that innovativeness $(\beta=0.334$, $\mathrm{t}=4.970, \mathrm{p}=0.000)$, competitive aggressiveness $(\beta=0.221, \mathrm{t}=3.715, \mathrm{p}=0.000)$ and risk taking $(\beta=0.136, \mathrm{t}=$ $2.044, p=0.042$ ) have positive and significant effects on sales volume of the selected quoted consumer goods companies in Nigeria. However, proactiveness $(\beta=0.129, \mathrm{t}=1.733, \mathrm{p}=0.000)$ and planning flexibility $(\beta=$ $0.075, t=1.378, p=0.169$ ) have a positive but insignificant effect on sales volume of selected quoted consumer goods companies in Nigeria. The study concluded that entrepreneurial orientation (innovativeness, competitive aggressiveness, proactiveness, risk-taking and planning flexibility) had significant effect on sales volume of selected quoted consumer goods companies in Nigeria and recommended that managers should be more aggressive in exploiting opportunities to increase sales volume.
\end{abstract}

Keywords: Entrepreneurial orientation, Sales volume, Consumer goods companies, Nigeria.

DOI: $10.7176 / \mathrm{JRDM} / 80-03$

Publication date: November $30^{\text {th }} 2021$

\subsection{Introduction}

Organizations like manufacturing companies around the globe are experiencing continuous challenges of maintaining stability regarding fundamental performance indicators across different years of business functioning. Consumer goods manufacturing industry managers find it challenging and difficult in constantly and continuously achieving targeted business performance indicators like sales volume, market share, sales growth, and competitive advantage resulting from global economic activities, unstable economic factors and open market competition challenges that are characterized with the consumer goods manufacturing industry. These challenges have created high volatile trend and deterioration in business performance indicators, and thus, capture the interests of scholars and professionals in strategic and entrepreneurship management to investigate the causes of volatility and deterioration in consumer goods industry performance indicators. Deloitte Report (2020) showed that the deterioration in overall performance of consumer goods firms is so common all over the world including developed economies. In emerging economies like China, Singapore, and Malaysia, Deloitte Report (2020) reported that consumer goods companies like food and beverages companies account for decline in profitability, low market share due to global competition and open market policies in China and Singapore.

Like other developing regions, Nigeria consumer goods manufacturing industry has long been associated with substantial gaps in port, road, power infrastructure, poor supply network, high cost of manufacturing processes, input and output; not to mention its notoriously high levels of corruption and bureaucratic restrictions, which increase the cost of distribution and investment, thus cause the rundown of performance indicators such as sales growth in the Nigeria consumer goods manufacturing industry (Manufacturing Association of Nigeria (MAN), 2019). Ojeleye, Opusunju, and Abdullahi (2020) emphasized that part of the factor hindering growth and continuous performance in Nigeria consumer goods manufacturing industry relates to poor quality and nonavailability of inputs in the local market, such as raw materials and equipment as well as limited size of the domestic market for manufactured products. The consumer goods manufacturing companies in Nigeria are yet to fully apply corporate entrepreneurial orientation techniques in managing unstable economic policies to accomplish a boost in their sales volume. (Egbunike \& Okerekeoti, 2018).

However, Adegbuyi, Oladele, Iyiola, Adegbuyi, Ogunnaike, Ibidunni and Fadeyi (2018) and Olubiyi et al. (2019) pointed that most of manufacturing companies in Nigeria do not strategically employ entrepreneurial 
orientation measure in managing challenges of unstable economic policies, thus reduce sales volume. Due to unpredictable economic factors, dynamic business environment and importation competitive landscape surrounding Nigeria consumer goods industry, there exist complexity and uncertainty in achieving performance indicators (Egbunike \& Okerekeoti, 2018). On the above negative notes and background challenges, this study assessed entrepreneurial orientation (innovativeness, competitive aggressiveness, proactiveness, risk-taking, planning flexibility) and sales volume of quoted selected consumer goods manufacturing companies in Nigeria.

\subsection{Literature Review \\ Conceptual Framework \\ Entrepreneurial orientation}

Mwangi and Ngugi (2014) defined entrepreneurial orientation as the process and decision making activities used by entrepreneurs that lead to entry and support of business activities with strategy- making processes that provide organizations with a basis for entrepreneurial decisions and actions in order to achieve firm performance. Etim, Adabu, and Ogar (2017) view entrepreneurial orientation as a set of decision-making styles, processes, practices, rules, and norms according to which a firm makes decisions to enhance its innovativeness, proactiveness and risk taking propensity. Omisakin, Nakhid, Littrell, and Verbitsky (2016) also conceptualized entrepreneurial orientation as the willingness of an entrepreneur to innovate, search for risks, take self-directed actions, and be more proactive and aggressive than competitors towards new market place opportunities so as to gain market share. Many scholars agree that EO is a combination of innovativeness, proactiveness, and risk taking (Ketchen \& Short 2012; Okangi, 2019).

Okangi (2019) further stated that the feature of entrepreneurial orientation is building an entrepreneurial orientation can be valuable to organizations and individuals alike in identifying and seizing new opportunities. Entrepreneurial orientation features are five dimensions: (1) autonomy, (2) competitive aggressiveness, (3) innovativeness, (4) proactiveness, and (5) risk taking. The advantages of entrepreneurial orientation are that entrepreneurial orientation is an intangible firm resource that creates competitive advantage and eventually promotes firm performance while the disadvantages are that wrongly application and employment of entrepreneurial orientation could adversely affect firm objectives, goals and overall performance (Okangi, 2019).

\section{Innovativeness}

Kiveu, Namusonge, and Muathe (2019) defines innovativeness as the introduction of a product which is new to consumers or with higher quality than existing products, new methods of production, the opening of new markets, the use of new sources of supply and new forms of competition, that lead to the restructuring of an industry. Mkalama, Ndemo, and Maalu (2018) defined innovativeness as the generation and implementation of new or improved processes, products/services, production methods aimed at increasing the competitiveness of an enterprise. OECD (2018) defined innovativeness as the implementation of a new or significantly improved product (good or service), or process, a new marketing method, or a new organisational method in business practices, workplace organisation or external relations (OECD, 2018).

Innovativeness is one of the key features of entrepreneurial behaviour linked to manufacturing companies (Ejdys, 2016). It is considered a dominant factor in firm competitiveness and the single most important factor in enhancing and sustaining competitiveness (Ejdys, 2016). Innovativeness is a key practice underpinning the survival and competitiveness of firms in a competitive globalised environment (Sheu, 2007; Lin \& Chen, 2007). Within the business context, innovation is considered the basis of strategic change through which firms can gain and sustain competitive advantage (Lin \& Chen, 2007).

Kiveu, Namusonge and Muathe (2019) further stated that the features of innovativeness include adaptations, refinement, enhancements or line extensions; this is the most common features of innovativeness in many organisations. Kiveu et al. (2019) stated that the advantages of innovativeness increase global competitive advantage, shortened product lifecycles and ease of imitation make it necessary for firms to innovate to sustain competitiveness (Hamid \& Tasmin, 2013). Hence pressure on all businesses to continually innovate by developing and launching new products and services is greater than ever (Wales, 2016). Innovativeness has thus become central to firm strategies and policies in the pursuit of firm competitiveness.

\section{Competitive Aggressiveness}

Linyiru and Ketyenya (2017) defined competitive aggressiveness as a strong struggle to overcome the competitors; it is characterized by a combative attitude or aggressive response, which seeks a better positioning in the market or defeat threats. Competitive aggressiveness, which has a relation with the organization's propensity, intensely and directly challenges its competitors reaching better market position, seeking to overcome competitors (Li, Huang \&Tasai 2010). Aigboje (2018) view competitive aggressiveness as firm's propensity to intensively challenge its competitors to improve its market position and outperform industry rivals in a marketplace. Competitively aggressive firms are those who pay close attention to their competitors' actions 
and initiate a series of their own. In other words, they prefer to invest in competitive actions such as product launches, marketing campaigns and price competition more frequently than others. It is characterized as the speed and number of competitive actions taken by a firm in comparison to the firm's direct rivals (Muhonen, 2017).

\section{Proactiveness}

Kurgat, Weru and Wata (2019) defined proactiveness is an attempts to discover future opportunities, even when these opportunities may be somewhat unrelated to existing operations. Proactiveness is achievement oriented, emphasizing initiatives taking, anticipating, creating change, and predicting evolution towards a critical situation and early preparation prior to the occurrence of an impeding uncertainty of risk (Hernández-Sánchez, Cardella, \& Sánchez-García, 2020). Proactiveness as a dimension of entrepreneurial orientation is an opportunity seeking and forward-looking perspective that involves acting in anticipation of future demand and trends, and thereafter capitalizing on these opportunities to gain benefit (Kropp, Lindsay \& Shoham, 2008). A strong proactive behavior gives SMEs the ability to anticipate needs in the market place and the capability to anticipate competitor's needs (Eggers, Kraus, Hughes, Laraway, \& Snycerski, 2013).

Proactiveness refers to a process that aims at anticipating and acting on future opportunities in terms of products, technologies and markets (Schillo, 2011) rather than reacting to events after they unfold (Ketchen \& Short, 2012). Proactiveness aims at introducing new products ahead of competitors, strategically eliminating operations that are in the declining stages of the business life cycle (Bass, 2008). Proactiveness shows how firms relate to market opportunities by seizing the initiative in the market place (Yang et al., 2012). Proactive firms have the desire to be pioneers (Reijonen, Tammi, \& Saastamoinen, 2014) by acting in advance and capitalizing on emerging opportunities (Ketchen \& Short 2012).

\section{Planning Flexibility}

Planning flexibility implies being capability of multiple responses to an organisation internal and external environment (Fink \& Benz, 2019). Jonsson (2007) stated that flexibility means that organisation can 'hire and fire' its employee at will due to weak labour-market regulations. Flexibility can also be seen as the degree which an organisation is adaptable to administrative relations and the authority that are rested in situational expertise (Adonsi, 2003). Kozjek and Ferjan (2015) used functional flexibility, numerical flexibility, external flexibility, and internal flexibility organization flexibilty to describe organization flexibility. Goodwin (2012) sees numerical flexibility as the capability of organizations and employers to regulate the number of its employees. Wachsen and Blind (2011) see numerical flexibility as external and internal numerical flexibility. Wachsen and Blind (2011) stated that external flexibility can be regarded as the ability of an organization to modify the number of workers to the activities in the organisation through the use of diverse means of employment.

\section{Risk Taking}

Risk Taking refers to a firm's tendency to engage and the willingness to commit significant resources to opportunities with uncertain outcomes (Bran \& Vaidis, 2019). Risk taking ability helps firms to engage in bold rather than cautious actions (Ketchen \& Short, 2012). Risk taking was acting by entering unfamiliar region, committing large sum of money and utilizing resources for conducting business in an environment replete with ambiguity (Javad et al., 2015). According to Okunbanjo, Adewale, and Akinsulire (2017) risk taking embodies taking brave steps, measures and commitment of financial and non-financial resources by gambling into an unknown business area.

Adisa, Adeoye, and Okunbanjo (2016) opined that risk-taking was all about taking bold actions by venturing into the unknown, borrowing large, and/or committing significant resources to ventures in undefined regions. According to Keh, Nguyen and $\mathrm{Ng}$ (2007) and Wiklund and Shepherd (2005), risk taking refers to an inclination of an individual, group, or organisation to take daring steps such as entering unknown new markets, committing a large portion of the firm's resources to undertakings with uncertain outcomes and/or borrowing heavily.

\section{Sales Volume}

Sales was an activity involving selling of products and services in return of money or other compensation, which was initiated and completed by the seller, the owner of the goods (Pendharkar \& Pandey, 2011). Omondi (2017) define concept of sales volume as the process of improving a business performance in terms of sale growth. Dobbs and Hamilton (2007) view sales volume as a change in size over a defined time period of sales activities of the organizations. Similarly, Igbal, Ahmed, Ateeq and Javaid (2013) defined sales volume as the number of units sold by a fast moving consumer goods company in a specific business period. The increases in the numbers or quantity of goods sold were regarded as sale growth. When an organization sales increases, the organization could be said to be performing well in the market. Sales growth was the rise in the quantity or number of goods 
sold or services rendered in the normal operations of a firm in a specified period (Guest, 2011). Sales growth can be achieved through the sales agents or sales person, sales outlets among others. Guest (2011) postulated some factors that may influence sales growth of an organisation. The factors are categorised into internal factors and external factors.

There are some recognised advantages for using sales volume as a measure of performance of the business firm. Firstly, it is less dependent upon macro environmental variables such as the state of the economy. Secondly, sales volume helps managers to evaluate not only total market growth or decline but also trends in customers' selections among competitors thus assisting in the provision of many strategic decision-making situations. Thirdly, it is recognised that sales volume is the most important metric that can be used to judge the effectiveness of such marketing campaigns like branding initiatives, advertising campaigns, and customer relationship management programmes. Fourthly, sales volume is in fact a relative measurement against external benchmarks as it tells the firm how well it is doing relative to the competition as opposed to internal measures which may be biased. Aside from usual sales promotions and national marketing, firms can grow their sales volume through buying a competitor, by building strong relationships with existing customers, and by keeping sales volume growth as a priority key performance indicator at all times.

\section{Entrepreneurial Orientation Components and Sales Volume}

The study of Trestl (2016) examined impact of entrepreneurial orientation on innovation and sales revenue in terms of business performance within airlines. The study employed survey research design and revealed that entrepreneurial orientation components significantly affect sales revenue of airline firms. Firms are turning towards entrepreneurial orientation to promote continual innovation, rapid growth, value creation, competitive advantage as well as improve sales performance (Gupta \& Batra, 2016). Entrepreneurial orientation not only stimulates business development, job creation, economic growth, profitability, innovation, and income generation but also is a fundamental driver of the growth of an organization (Okangi, 2019). Elumah, Shobayo and Akinleye (2016) found that entrepreneurial orientation, positively affect sales growth. Mukutu (2017) found that entrepreneurial orientation positively enhances firm performance. Simao, Rodrigues, and Madeira (2016) asserted that entrepreneurial orientation practices have positive and significantly improve firm performance. Alpkan, Yilmaz, and Kaya (2007) recognized entrepreneurial orientation and organization flexibility as a natural source of competitive advantage of firms, and also planning flexibility is an effective tool to deal with the uncertainty created by rapid changes in the environment which enhance firms' performance.

On the other hand, Cingoz and Akdogan (2013) posit that entrepreneurial orientation negatively affect firm performance. Okangi (2019) also found that proactiveness dimension has a negative significant effect on firm performance. In the same vein, the study of Mukutu (2017) carried out on impact of corporate entrepreneurship strategy on growth of business organisations using stratified random sampling technique and sample size of 143 staff revealed that there was a positive and significant relationship between innovation, risk taking and proactiveness, market share and business growth at Safaricom $(\mathrm{K})$ Limited. He further showed that corporate entrepreneurship components significantly affect business growth at Safaricom (K) Limited. Empirically, Tavassoli and Karlsson (2015) asserted that market share and innovation is associated with product offers, promotion activities, product placements, design properties and pricing strategies which are determined by corporate entrepreneurship. Also, on the contrary, Auka and Keraro (2014) study on corporate entrepreneurship components and market share in the retail banking sector in Kenya. Their study empirically affirmed that there is an insignificant link between corporate entrepreneurship components and market share. Auka and Keraro (2014) study on corporate entrepreneurship components and market share in the retail banking sector in Kenya affirmed that there is an insignificant link between entrepreneurial orientation components and market share. 


\subsection{Conceptual Framework ENTREPRENEURIAL ORIENTATION}

SALES VOLUME

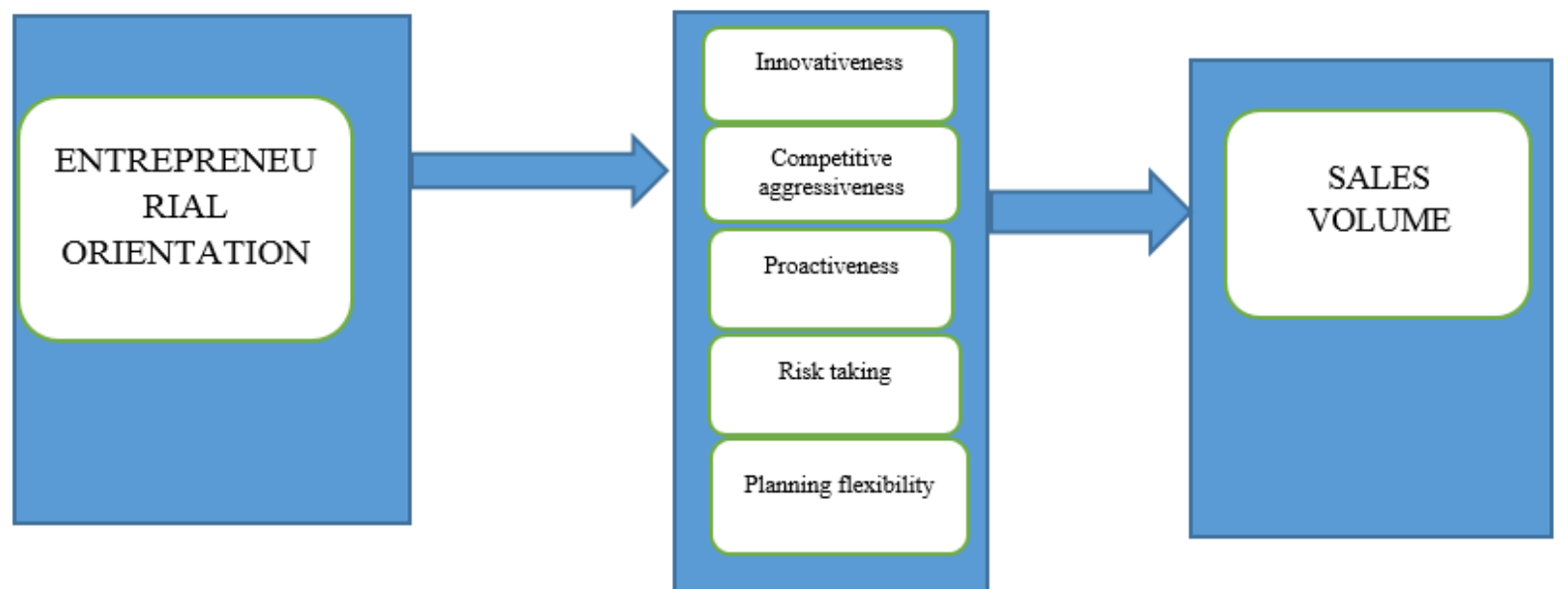

Researchers' conceptualisation (2021)

\subsection{Theoretical Framework}

This study adopted Resources-Based View (RBV) Theory and Entrepreneurship Innovation Theory (Barney, 1991; \& Schumpeter, 1949) as baseline theories for this study. These theories were selected to guide this study because their perspectives were tied to the focus of the study and the variables under investigation. The justification for these theories employed in this study were based on their theoretical explanation on the study variables; RBV states that the organizational resources and capabilities that were rare, valuable, nonsubstitutable, and imperfectly imitable form the basis for a firm's sustained competitive advantage and performance. Entrepreneurship Innovation Theory on its part, explains that innovation occurs when the entrepreneur introduces a new product or a new production system, opens a new market, discovers a new source of raw materials or introduces a new organization into the industry and in the process, enhances firm superior performance. Both Resource-based Theory and Entrepreneurship Innovation Theory capture the dynamics of the independent and dependent variables in this study.

\subsection{Methods}

\subsection{Research design}

This study adopts cross sectional survey research design which facilitated the use of a structured research instrument in obtaining data from the respondents for the study. Both top management and functional management staff were employed as population without considering other staff or lower cadre staff since decision makings towards entrepreneurial strategies are carried out by top and functional managers. Therefore, this study employed multi-stage sampling technique since the population of top management and functional Management staff is large. Data were analysed using descriptive and inferential (multiple regression analysis) statistics.

\subsection{Population of the Study}

The population for this research comprises twelve (12) quoted consumer goods manufacturing companies in Nigeria; Cadbury Nigeria Plc, Dangote Flour mills Plc, Dangote Sugar Refinery Plc, Flour Mill of Nigeria Plc, Guinness Nigeria Plc, Honeywell Flour mill Plc, Netsle Nigeria Plc, Nigerian Breweries Plc, PZ Cusson Nigeria Plc, 7-UP Bottling Company Plc, Unilever Nigeria Plc and Vitafoam Plc. These consumer goods manufacturing companies are selected because they are quoted on the Nigerian Stock Exchange (NSE) as at year 2020. The sample size for this study is determined by applying the Cochran (1997) formula: The sample of 494 was increased by 130 , or $30 \%$ of the total sample which equal 563 . This is as recommended by Zikmund (2000).

\subsection{Validity and Reliability of Research Instrument}

A pilot study was conducted to pre-test the questionnaire on 56 consumer goods manufacturing companies' staff $(10 \%$ of the sample size) which was randomly selected from the sample across other consumer goods manufacturing companies that were not part of consumer goods manufacturing companies used in this study. The consumer goods manufacturing companies were Multi-Trex Integrated Foods Plc, Nascon Allied Industries Plc, Nigerian Enamelware Plc, Union Dicon Salt Plc, and Champion Brew Plc and also eleven (11) 
questionnaires were distributed to each of the selected companies for pilot study. The total number of copies of the questionnaire retrieved from the sample was fifty-two (52). The responses were analyzed in order to determine the reliability of the research instrument. The result of the pilot study indicated that the research instrument was reliable, since the Cronbach's alpha of the scale for all the variables was greater than 0.70 .

\subsection{Model Specification}

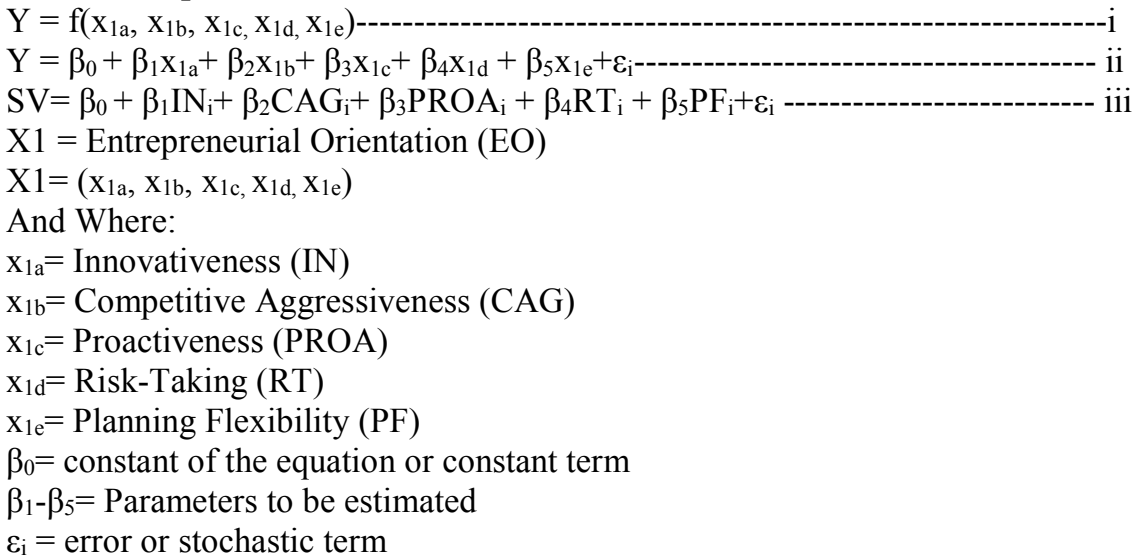

\subsection{Results and interpretation}

Entrepreneurial orientation components have no significant influence on sales volume of selected quoted consumer goods companies in Nigeria.

To test hypothesis, multiple regression analysis was used. The independent variable were entrepreneurial orientation components (innovativeness, competitive aggressiveness, proactiveness, risk-taking and planning flexibility) while the dependent variable was sales volume. In the analysis, data for entrepreneurial orientation components were created by adding together responses of all the items under the various components to generate independent scores for each component. For sales volume, responses of all items the variable were added together to create index of sales volume. The index of sales volume (as dependent variable) is thereafter regress on scores (index) of entrepreneurial orientation components (as independent variables). The results of the analysis and parameter estimates obtained are presented in Table 1.

Table 1: Summary Results of Multiple Regression Analysis of Sales Volume on Entrepreneurial Orientation Components of the selected quoted consumer goods companies in Nigeria.

\begin{tabular}{llllllll} 
Model & $\boldsymbol{B}$ & $\boldsymbol{T}$ & $\boldsymbol{S i g .}$ & $\boldsymbol{F ( 5 , 4 4 1 )}$ & $\mathbf{R}^{\mathbf{2}}$ & Adj. R$^{\mathbf{2}}$ & F(Sig) \\
(Constant) & 2.467 & 3.008 & .003 & 190.844 & 0.684 & 0.680 & 0.000 \\
Innovativeness & .334 & 4.970 & .000 & & & & \\
Competitive Aggressiveness & .221 & 3.715 & .000 & & & \\
Proactiveness & .129 & 1.733 & .084 & & & \\
Risk Taking & .136 & 2.044 & .042 & & & \\
Planning Flexibility & .075 & 1.378 & .169 & & & \\
\hline
\end{tabular}

a. Dependent Variable: Sales Volume

b. Predictors: (Constant), Innovativeness, Competitive Aggressiveness, Proactiveness, Risk Taking, Planning Flexibility.

Source: Researchers' Field Survey, 2021

Table 1 detailed multiple regression results for the effect of entrepreneurial orientation components (innovativeness, competitive aggressiveness, proactiveness, risk-taking and planning flexibility) on sales volume of the selected quoted consumer goods companies in Nigeria. The results revealed that innovativeness $(\beta=0.334$, $\mathrm{t}=4.970, \mathrm{p}=0.000)$, competitive aggressiveness $(\beta=0.221, \mathrm{t}=3.715, \mathrm{p}=0.000)$ and risk taking $(\beta=0.136, \mathrm{t}=$ $2.044, p=0.042$ ) have positive and significant effects on sales volume of the selected quoted consumer goods companies in Nigeria. However, proactiveness $(\beta=0.129, \mathrm{t}=1.733, \mathrm{p}=0.000)$ and planning flexibility $(\beta=$ $0.075, \mathrm{t}=1.378, \mathrm{p}=0.169$ ) have a positive but insignificant effect on sales volume of selected quoted consumer goods companies in Nigeria. This implies that innovativeness, competitive aggressiveness and planning flexibility are significant predictor of sales volume of selected quoted consumer goods companies in the study area.

The results further revealed that entrepreneurial orientation components (innovativeness, competitive aggressiveness, proactiveness, risk-taking and planning flexibility) explained $68 \%$ of the variation in sales volume of the selected quoted consumer goods companies $\left(A d j . R^{2}=0.680\right)$. However, the model did not explain $31.6 \%$ of the variation in sales volume of the selected quoted consumer goods companies in Nigeria, implying 
that there are other factors associated with sales volume of the selected quoted consumer goods companies that were not captured in the model. This concurs with Graham and Coffman (2012) that R-squared is always between 0 and 100\%: $0 \%$ indicates that the model explains none of the variability of the response data around its mean and $100 \%$ indicates that the model explains the variability of the response data around its mean. In general, the higher the $R$-squared, the better the model fits the data. The adjusted $R$ square was slightly lower than the $R$ square which implied that the regression model may be over fitted by including too many independent variables.

Also, the results of Analysis of Variance (ANOVA) for regression coefficients used to test the overall significance of regression model has the value of 190.844 with $(5,441)$ degrees of freedom and p-value of 0.000 which was less than $0.05\left(F_{(5,411)}=190.844, \mathrm{p}=0.000\right)$. This implies that the overall model was significant in predicting the sales volume of the selected quoted consumer goods companies in Nigeria. That is, sales volume is affected by entrepreneurial orientation components (innovativeness, competitive aggressiveness, proactiveness, risk taking and planning flexibility) and the F-value standing at 190.844 . The result shows that at least one of the entrepreneurial orientation components has a significant effect on the sales volume of the selected quoted consumer goods companies in Nigeria. In coming up with the final regression model to predict sales volume of the selected quoted consumer goods companies in Nigeria, the entrepreneurial orientation components are statistically significant and were retained in the model. The multiple regression model from the results is thus expressed as:

$\mathrm{SV}=2.467+0.334 \mathrm{IN}+0.221 \mathrm{CA}+0.136 \mathrm{RT}$

Where:

$$
\begin{aligned}
& \text { SV = Sales Volume } \\
& \text { IN = Innovativeness } \\
& \text { CA = Competitive Aggressiveness } \\
& \text { RT = Risk Taking }
\end{aligned}
$$

From the above regression equation above, it was revealed that holding entrepreneurial orientation components (innovativeness, competitive aggressiveness and risk taking) constant (at zero), sales volume of the selected quoted consumer goods companies in Nigeria will be 2.467 . This implies that if innovativeness, competitive aggressiveness and risk taking take on the values of zero (do not exist), there would be 2.467 times level of repetition of the sales volume of the selected quoted consumer goods companies in Nigeria. The model shows that a unit change in innovativeness, competitive aggressiveness and risk taking respectively will lead to $0.334,0.221$ and 0.136 unit changes in sales volume of the selected quoted consumer goods companies in Nigeria. The results revealed that innovativeness $(B=0.334, t=4.970, p=0.000<0.05)$ was the most significant predictor (among entrepreneurial orientation components) on sales volume of the selected quoted consumer goods companies in Nigeria while competitive aggressiveness was the next most significant predictor of sales volume of the selected quoted consumer goods companies in Nigeria. Since most of the regression coefficients were significant at 5\% significance level as indicated in Table 1, the null hypothesis was rejected. Therefore, the null hypothesis $\left(\mathrm{H}_{0}\right)$ which states that there is no significant effect of entrepreneurial orientation components on sales volume of selected quoted consumer goods companies in Nigeria is hereby rejected.

\section{Discussion of findings}

The results of linear multiple regression analysis for the effect of entrepreneurial orientation components on sales volume of selected quoted consumer goods companies in Nigeria showed the presence of a significant effect. This result indicated that entrepreneurial orientation components significantly influenced sales volume of selected quoted consumer goods companies in Nigeria. Conceptually, scholars have reported that entrepreneurial orientation components significantly influenced sales volume: Trestl (2016) examined impact of entrepreneurial orientation on innovation and sales revenue in term of business performance within airlines. The study employed survey research design and revealed that entrepreneurial orientation components significantly affect sales revenue of airline firms. Firms are turning towards entrepreneurial orientation to promote continual innovation, rapid growth, value creation, competitive advantage as well as improve sales performance (Gupta \& Batra, 2016). Entrepreneurial orientation not only stimulates business development, job creation, economic growth, profitability, innovation, and income generation but also is a fundamental driver of the growth of an organization (Okangi, 2019). Elumah, Shobayo and Akinleye (2016) found that entrepreneurial orientation, positively affect sales growth. Mukutu (2017) that found that entrepreneurial orientation positively enhances firm performance. Simao, Rodrigues, and Madeira (2016) asserted that entrepreneurial orientation practices have positive and significantly improve firm performance.

In addition, Patil and Marathe (2016) findings suggested that market orientation and planning flexibility positively influence firm performance; planning flexibility exerts a negative pressure on performance in highly dynamic markets. Varis and Littunen (2016) adopted a regression model to analyse the relation between business performance, market share and corporate entrepreneurship components, finding revealed a significant relationship between corporate entrepreneurship components, market share business performance. On the 
contrary, Auka and Keraro (2014) study on corporate entrepreneurship components and market share in the retail banking sector in Kenya. Their study empirically affirmed that there is an insignificant link between entrepreneurial orientation components and market share. This study's findings are in line with the assumptions of Resources-Based View (RBV) Theory and Entrepreneurship Innovation Theory and thus, in support of the result that entrepreneurial orientation components significantly influenced sales volume of selected quoted consumer goods companies in Nigeria. Hence, in line with revelations found in conceptual, empirical and theoretical submissions in previous literature with this present study's result, entrepreneurial orientation components significantly influenced the sales volume of selected quoted consumer goods companies in Nigeria.

\section{Conclusion}

Considering the empirical findings, this study concluded that entrepreneurial orientation components significantly influenced sales volume of selected quoted consumer goods companies in Nigeria.

\section{Recommendations}

In line with the findings of the study that entrepreneurial orientation components have influence on sales volumes of selected quoted consumer goods companies in Nigeria. The study, therefore, recommended that quoted consumer goods companies managers should practice entrepreneurial orientation ideologies so as to be in comfortable position in terms of boosting their sales volume for organisational sustainability.

\subsection{Suggestion for further studies}

Future researchers could employ longitudinal survey research design to capture the dynamics of entrepreneurial orientation and overall firm performance measures in the consumer goods industry. Also, future researchers could carry out a comparative study of other industries and consumer goods industry so as to observe and compare this study's findings with other industries and this will enable the researcher to compare results.

\section{References}

Adegbuyi, A. A., Oladele, P., Iyiola, O. O., Adegbuyi, O. A., Ogunnaike, O. O., Ibidunni, A. S., \& Fadeyi, O. (2018). Assessing the influence of entrepreneurial orientation on small and medium enterprises' performance. International Journal of Entrepreneurship, 22(4), 1-7

Adisa, M. K., Adeoye, A. O., \& Okunbanjo, O. I. (2016). The impact of entrepreneurship orientation on entrepreneurs compensation in Nigeria. International Journal of Economics, Business and Management Studies, 3(3), 102-116.

Adonisi, M. P. (2003). The relationship between corporate entrepreneurship, market orientation, organizational flexibility and job satisfaction. (Dissertation) University of Pretoria, Pretoria.

African Economic Outlook (AEO) (2020). https://www.afdb.org/en/knowledge/publications/african-economicoutlook

Aigboje, P. O. (2018). Competitive aggressiveness and organizational profitability of hotels in Port Harcourt, Nigeria. International Journal of Social Sciences and Management Research, 4(5), 37-44.

Alpkan, L., Yilmaz, C., \& Kaya, N. (2007). Owner-managers and business planning in the small firm. International Small Business Journal, 25(2), 152-172.

Auka, D. O., \& Keraro, O. J. (2014). Strategic marketing and technological innovations and firm growth: The case of retail banking in Kenya. Sky Journal of Business Administration and Management, 2(8), 037-053.

Barney, J. (1991). Looking inside for competitive advantage. Academy of $\quad$ Management Executive, 9 (4), 49-61.

Bass, B. M., \& Bass, R. (2008). The Bass handbook of leadership: Theory, research, and managerial applications $\left(4^{\text {th }}\right.$ ed.). New York. Free Press.

Bran, A., \& Vaidis, D. (2019). Choose your own risks: measuring risk-taking through an interactive novel. Laboratoire de psychologie sociale, université Paris descartes, Paris, France.

Cingöz, A., \& Akdoğan, A. A. (2013). Strategic flexibility, environmental dynamism, and innovation performance: An empirical study. Procedia-Social and Behavioral Sciences, 99, 582-589.

Cochran, W. G. (1997). Sampling techniques (3 ${ }^{\text {rd }}$ ed.). New York: John Wiley \& sons.

Deloitte Report (2020). https://www2.deloitte.com/by/en/pages/consumer-business/solutions/food-beverage.html

Dobbs, M., \& Hamilton, R. T. (2007). Small business growth: recent evidence and new directions. International Journal of Entrepreneurial Behavior \& Research, 12(9)5.

Egbunike, C. F., \& Okerekeoti, C. U. (2018).Macroeconomic factors, firm characteristics and financial performance. Asian Journal of Accounting Research, 4(16), 55-62.

Eggers, F., Kraus, S., Hughes, M., Laraway, S., \& Snycerski, S. (2013). Implications of customer and entrepreneurial orientations for SME growth. Management Decision, 4(8), 12-25.

Ejdys, J. (2016). Entrepreneurial orientation vs. innovativeness of small and medium size enterprises. Journal of 
Engineering, Project, and Production Management, 6(1), 13-24.

Elumah, L. O., Shobayo, P. B., \& Akinleye, D. B. (2016). Impact of entrepreneurial orientation and entrepreneurial management on firm growth: Evidence from Nigeria manufacturing industry. Conference Paper, University of Professional Studies, Accra, Ghana.

Etim, J. J., Adabu, M.U., \&Ogar, C.A. (2017). Influence of entrepreneurial orientation as survival strategy for small and medium enterprises: The Nigeria experience. International Journal of Economics, Commerce and Management, 2(2), 502-518

Fink, S., \& Benz, F. (2019). Flexibility planning in global inbound logistics. Procedia CIRP, 79, 415-420.

Goodwin, A. (2012). EMU Market Dynamics: Labour Market Flexibility in Europe. CBI Organisation, Great Britain.

Gupta, V. K., \& Batra, S. (2016). Entrepreneurial orientation and firm performance in Indian SMEs: Universal and contingency perspectives. International Small Business Journal, 34(5), 660-682.

Guest, D. (2011). Human resource management and performance: Still searching for some answers. Human resource management journal, 21(1), 3-13.

Hamid, N. A., \& Tasmin, R. (2013). The relationship of business innovation capabilities and technology innovation capabilities on SME organization performance: a conceptual framework. Economics and business, 4(4), 65-78.

Hernández-Sánchez, B. R., Cardella, G. M., \& Sánchez-García, J. C. (2020). Psychological Factors that Lessen the Impact of COVID-19 on the Self-Employment Intention of Business Administration and Economics' Students from Latin America. International Journal of Environmental Research and Public Health, 17(15), 52-93.

Igbal, N., Ahmed, N., Ateeq, M., \& Javaid, K. (2013). Roles of sales promotion on sales volume in the context of fast moving consuming goods industry in Dera Ghan Khan. International journal of accounting research, $1(4), 21-28$

Javad, M. Y., Alireza, K., \& Yaghoob, M. (2015). Organizational Entrepreneurship and its Impact on the Performance of Governmental Organizations in the City of Mashhad. Procedia-Social and Behavioral Sciences, 169(20), 75-87.

Jonsson, D. (2007). Flexibility, stability and related con-cepts. In Furlker, B., Híkansson, K. \& Karlsson, J. (Eds.), Flexibility and stability in working life. Hampshire: Palgrave Macmillan.

Keh, H. T., Nguyen, T. T. M., \& Ng, H. P. (2007). The effects of entrepreneurial orientation and marketing information on the performance of SMEs. Journal of business venturing, 22(4), 592-611.

Ketchen, D., \& Short, J. (2012). Strategic management: Evaluation and execution. New York: Creative Common.

Khan, H., \& Wisner, J. D. (2019). Supply chain integration, learning, and agility: Effects on performance. Journal of Operations and Supply Chain Management, 12(1), 14.

Kiveu, M. N., Namusonge, M., \& Muathe, S. (2019). Effect of innovation on firm competitiveness: the case of manufacturing SMEs in Nairobi County, Kenya. International Journal of Business Innovation and Research, 18(3), 307-327.

Kozjek, T., \& Ferjan, M. (2015). Organisational flexibility, employee security, and organisational efficiency- a case of Slovenian public and private sector organisations. Organizacija, 48. DOI: 10.1515/Oga.

Kropp, F., Lindsay, N., \& Shoham, A. (2008). Entrepreneurial orientation and international business venture startup. International journal of entrepreneurial behaviour and research, 14(2),102-117.

Kurgat, E. K., Weru, I., Wata, D. (2020). Proactive risk assessment of vincristine use process in a teaching and referral hospital in Kenya and the implications. Journal of Oncology Pharmacy Practice, 26(3), 666-679. Kwon, S. J., Ryu, D., \& Park, E. (2018). The influence of entrepreneurs' strategic agility and dynamic capability on the opportunity pursuit process of new ventures: Evidence from South Korea. Academy of Strategic Management Journal, 17(1), 1-17.

Li, Y. H., Huang, J. W., \& Tsai, M.T. (2010). Entrepreneurial orientation and firm performance: The role of knowledge creation process. Industrial Marketing Management, 38(4), 440-449.

Lin, C. Y., \& Chen, M. Y. (2007). Does innovation lead to performance? An empirical study of SMEs in Taiwan. Management research news, 30 (2), 115-132.

Linyiru, B. M., \& Ketyenya, R. P. (2017). Influence of competitive aggressiveness on performance of state corporations in Kenya. International Journal of Entrepreneurship, 2(1), 1-14.

Manufacturing Association of Nigeria

(MAN) (2019).https://www.manufacturersnigeria.org/ManInDailyNigerianNews

Mkalama, B. W., Ndemo, B. E., \& Maalu, J. K. (2018). The antecedents of innovativeness in small and medium manufacturing enterprises in Kenya: A critical review of literature. African Journal of Business Management, 12(17), 527-535.

Muhonen, S. (2017). The profitability of competitive aggressiveness: The moderating effect of industry-related 
and organizational factors. A thesis submitted at Aalto University School of Business Department of Marketing. Mukutu, J. K. (2017). Impact of corporate entrepreneurship strategy on growth of business organisations: A case of safaricomlimited. a research project proposal submitted to the chandaria school of business in partial fulfillment of the requirement for the Degree of Masters in Business Administration $(M B A)$.

Mukutu, J. K. (2017). Impact of corporate entrepreneurship strategy on growth of business organisations: A case of Safaricom Ltd. A resaearch project proposal submitted to the Chandaria School of Business. in partial fulfilment of the requirement for the degree of MBA.

Mwangi, S. M., \& Namusonge, M. J. (2014). Influence of innovation on small and medium Enterprise (SME) growth-A case of garment manufacturing Industries in Nakuru County. International Journal for Innovation Education and Research, 2(6), 101-107.

Ojeleye, Y. C., Opusunju, M. I., \&Abdullahi, A. I. (2020). Globalisation and performance of manufacturing sector in Nigeria. Journal of Accounting and Management, 3(1), 12-18.

Okangi, F. P. (2019). The impacts of entrepreneurial orientation on the profitability growth of construction firms in Tanzania. Journal of Global Entrepreneurship Research, 9(1), 14-31.

Okunbanjo, I. O., Adewale, O. M., \& Akinsulire, O. H. (2016). Effect of entrepreneurs' character on SMEs performance in Lagos State, Nigeria. Journal of Management and Science, 7(3), 17-26.

Olubiyi, T. O., Egwakhe, A. J., Amos, B., \& Ajayi, A. A. (2019). Entrepreneurial Orientation and Firm Profitability: Evidence from Lagos State Nigeria. Entrepreneurial Orientation and Firm Profitability: Evidence from Lagos State Nigeria, 21(6), 42-54.

Omisakin, O., Nakhid, C., Littrell, R., \& Verbitsky, J. (2016). Entrepreneurial orientation among migrants and small and medium enterprises. International journal of business and management review, 3(4), 7-22.

Omondi, O. J. (2017). Impact of Digital Marketing on sales growth of small and medium enterprises in Nairobi, Kenya. Research Project submitted to School of Business, University of Nairobi.

Organisation for Economic Co-operation and Development (2019).https://www.oecd.org/development/development-co-operation-report-20747721.htm

(OECD)

Patil, S. T., \& Marathe, S. (2016). Market orientation and flexibility in production planning in SMEs: An empirical study. International Research Journal of Multidisciplinary Studies, 2(7), 12-24.

Pendharkar, A., \& Pandey, V. K. (2011). Personality and sales performance (An empirical investigation). Central Test The Art of Assessment.

Reijonen, H., Tammi, T., \& Saastamoinen, J. (2016). SMEs and public sector procurement: Does entrepreneurial orientation make a difference?. International Small Business Journal, 34(4), 468-486.

Schillo, R. S. (2011). Entrepreneurial orientation and company performance: can the academic literature guide managers?. Technology Innovation Management Review, 1(2), 43-58.

Schumpeter, J. A. (1949). Economic theory and entrepreneurial history in Wohl, R.R. (ed.). Change and the entrepreneur: postulates and the patterns for entrepreneurial history and research centre in entrepreneurial history, Cambridge, Massachussetts: Harvard University Press.

Sheu, J. B. (2017). Buyer behavior in quality - dominated multi - sourcing recyclable - material procurement of green supply chains. Production and Operations Management, 25(3), 477-497.

Simao, L. B., Rodrigues, R. G., \& Madeira, M. J. (2016). External relationships in the organizational innovation. RAI Revista de Administração e Inovação, 13, 156-165.

Tavassoli, S., \& Karlsson, C. (2015). Innovation strategies and firm performance. Centre of Excellence for Science and Innovation Studies Working Paper Series, 401, 1-31.

Trestl, M. (2016). Korporatīvās uzñēmējdarbības ietekme uz aviokompāniju inovācijām un uzṇēmējdarbības panākumspēju. Retrieved from https://dspace.lu.lv/dspace/handle/7/31375

Varis, M., \& Littunen, H. (2016). Types of Innovation, Sources of Information and Performance in Entrepreneurial SMEs. European Journal of Innovation Management, 13 (2), 128-154

Wachsen, E., \& Blind, K. (2011). More flexibility for more innovation? Working Paper 115, University of Amsterdam. Retrieved 29. 08. 2020 from: http://www.uvaaias.net/uploaded_files/publications/WP115Wachsen,Blind.pdf

Wales, W. J. (2016). Entrepreneurial orientation: A review and synthesis of promising research directions. International Small Business Journal, 34(1), 3-15.

Wiklund, J., \& Shepherd, D. (2005). Entrepreneurial orientation and small business performance: a configurational approach. Journal of Business Venturing, 20(1), 71-91.

Woschke, T., Haase, H., \& Kratzer, J. (2017). Resource scarcity in SMEs: effects on incremental and radical innovations. Management Research Review, 4(5), 87.

Yang, C., \& Liu, H. M. (2012). Boosting firm performance via enterprise agility and network structure. Management Decision, 50(6), 1022-1044.

Zikmund, W. G. (2000). Business research methods ( $6^{\text {th }}$ ed.). The Dryden Press, Fort Worth. 